\title{
Antitumor Activity of the Combination of Artemisinin and Epirubicin in Human Leukemia Cells
}

\author{
Margarita Y. Zhelyazkova ${ }^{1}$, Nadya G. Hristova-Avakumova ${ }^{2}$, Georgi Tsv. Momekov ${ }^{1}$ \\ ${ }^{1}$ Department of Pharmacology, Pharmacotherapy and Toxicology, Faculty of Pharmacy, Medical University of Sofia, Sofia, Bulgaria \\ ${ }^{2}$ Department of Medical Physics and Biophysics, Medical University of Sofia, Sofia, Bulgaria
}

Corresponding author: Margarita Y. Zhelyazkova, Department of Pharmacology, Pharmacotherapy and Toxicology, Faculty of Pharmacy, Medical University of Sofia, Sofia, Bulgaria; E-mail: maggie.zhe1711@gmail.com; Tel.: 029236509

Received: 29 June 2020 Accepted: 30 July $2020 \diamond$ Published: 31 Aug 2021

Citation: Zhelyazkova MY, Hristova-Avakumova NG, Momekov GTsv. Antitumor activity of the combination of artemisinin and epirubicin in human leukemia cells. Folia Med (Plovdiv) 2021;63(4):488-95. doi: 10.3897/folmed.63.e55938.

\section{Abstract}

Aim: We evaluated the tumor-inhibiting effect of artemisinin applied separately and in combination with epirubicin on leukemia HL-60 and HL-60/Dox cell lines, its dose modulation effect and its potency to influence iron-induced oxidative damage of biologically relevant molecules.

Materials and methods: MTT assay and the method of Chou-Talalay were used to show the inhibition of tumor cell proliferation and to evaluate the synergistic effect and modulation effect of artemisinin and epirubicin at varying concentrations. We also used spectrophotometric assays to determine the potency of artemisinin to influence iron-induced molecular degradation of lecithin and deoxyribose.

Results: Artemisinin exhibits tumor-inhibiting effect on both the anthracycline-sensitive and anthracycline-resistant promyelocytic cell lines, reaching $88 \%$ and $61 \%(\mathrm{~T} / \mathrm{C})$, respectively, when applied at higher concentrations in a dose-dependent manner. The combination of artemisinin and epirubicin shows synergistic effects in all tested concentrations on doxorubicin-resistant cells $(\mathrm{CI}<0.7)$. Artemisinin sensitizes the resistant cells towards epirubicin as shown by the CI (combination index) values and has a dose-modulation effect as shown by DRI (dose reduction index). Artemisinin induces deoxyribose oxidative degradation when applied alone and exerts synergistic deoxyribose degradation effect when applied with iron. However, artemisinin does not influence the studied processes in the lecithin-containing model system and has no potential to induce lipid peroxidation.

Conclusions: This study presents a new opportunity to enhance the effectiveness of epirubicin-based treatment regimens with addition of artemisinins for resistant tumors.

\section{Keywords}

combination chemotherapy, deoxyribose, HL-60/Dox, lecithin, synergism

\section{INTRODUCTION}

Resistant tumors are subject to many investigations in the field of combination chemotherapy. Epirubicin (EPI), an anthracycline antibiotic, is widely used for the treat- ment of solid tumors. Despite the remarkable anticancer activity of EPI, its high-dose therapeutic use is limited by cardiotoxicity and secondary drug resistance. ${ }^{1}$ Therefore, its inclusion in combination treatment may be highly desirable. 
Traditional medicinal herbs are widely used as an attractive source of therapeutic regimens without a severe toxicity. So is Artemisia annua L., belonging to the plant family of Asteraceae and containing the biologically active sesquiterpene lactone artemisinin (ART), with a unique 1,2,4-trioxane ring that causes free radical-induced damage. For many years, ART has been effectively used for the treatment of drug-resistant malaria. Today, this drug and its semisynthetic derivatives, named artemisinins, are produced thanks to a modern biotechnological approach. ${ }^{2}$ They possess antimalarial, antitumor, and antiviral activity, block the angiogenesis and inhibit metastases. ${ }^{3-6}$ Also, they induce apoptosis and ferroptosis by producing carbon-centered radicals following bioactivation with iron. ${ }^{7-11}$ Thus, they are a typical example of bioreductive drugs, such as mitomycin, etoposide, and some quinone-containing agents. ${ }^{12}$ In addition, lysosome-induced autophagy has been described as another mechanism of action. ${ }^{4,13}$

Some of the artemisinins such as dihydroartemisinin, artesunate, and artemisone enhance the antitumor potential of oxaliplatin, carboplatin, gemcitabine or doxorubicin. ${ }^{5,9,14}$ But data for ART remains contradictory and limited: there is evidence for additive effect in combination with thalidomide, and antagonism in combination with oxaliplatin and gemcitabine on colon and mammary tumor cells. ${ }^{15,16}$ Some authors hypothesized that the combination of artemisinins with cytostatics may improve their antitumor activity on resistant cells due to chemosensitization and radical-mediated cytotoxicity. ${ }^{17}$

\section{AIM}

In this study we evaluated the effectiveness of epirubicin-based combinations with artemisinin on sensitive HL-60 and resistant to anthracyclines HL-60/Dox cell lines, its dose modulation effect and its potency to influence iron-induced oxidative damage of biologically relevant molecules.

\section{MATERIALS AND METHODS}

\section{Reagents, reactives and drugs}

The chemicals used in the spectrophotometric assays were obtained from Sigma-Aldrich and are presented under the correlating figures; artemisinin, caps. $100 \mathrm{mg}$ from Science-Based Nutrition, USA; epirubicin (Farmorubicin, fl 2 $\mathrm{mg} / \mathrm{ml}$ ) from Pfizer; MTT (3-(4,5-dimethiazol-2-yl)-2,5diphenyltetrazolium bromide) from Genaxxon.

\section{Cell lines and culture}

HL-60 and HL-60/Dox promyelocytic leukemia cell lines were obtained from DSMZ (Braunschweig, Germany). The cells were maintained at $37^{\circ} \mathrm{C}$ under an atmosphere of $5 \% \mathrm{CO}_{2}$ in RPMI-1640 medium supplemented with $10 \%$ heat-inactivated fetal bovine serum, L-glutamine (final concentration $2.5 \mathrm{mM})$ and antibiotics $(100 \mathrm{U} / \mathrm{ml}$ penicillin and $100 \mu \mathrm{g} / \mathrm{ml}$ streptomycin).

\section{MTT assay}

A slightly modified version of MTT assay was performed to determine the cell survival fraction. ${ }^{18}$ Exponentially growing HL-60 and HL-60/Dox cells were seeded into 96well plates. The cells were treated with the indicated drugs in 3-5 different concentrations, and the cell viability was determined after 72 hours of incubation, adding MTT (10 $\mathrm{mg} / \mathrm{ml}$ ). Absorption was measured by an automated microtiter plate spectrophotometer (Labexim LMR-1, Lengau, Austria) at $550 \mathrm{~nm}$.

\section{Method of Chou-Talalay ${ }^{19,20}$}

We applied the mathematical algorithm of Chou to assess the effectiveness of the combination [ART+EPI] in varying and fixed-ratio concentrations based on the median effect (Fa) of the two drugs applied separately and simultaneously derived from the cell vitality assay. According to this method, the combination index (CI) value for each concentration scheme less than 0.9 denotes synergism, $\mathrm{CI}=0.9$ 1.10 denotes additive interaction, and CI more than 1.10 denotes antagonism; the dose-reduction index (DRI) equal to one denotes no dose reduction, whereas DRI $>1$ and $\mathrm{DRI}<1$ indicates favourable and unfavourable dose-reduction, respectively. In addition, we analyzed bioequivalent concentrations $\left(\mathrm{IC}_{50}\right)$ for some of the schemes.

\section{Iron-induced oxidative molecular damage}

The assay was performed by using a modification of the ferrous iron method described by Asakawa and Matsushita. ${ }^{21}$ The samples were prepared in phosphate buffer $\left(\mathrm{K}_{2} \mathrm{HPO}_{4} /\right.$ $\mathrm{KH}_{2} \mathrm{PO}_{4}, \mathrm{pH} 7.4$ ) with equivalent concentrations of the oxidizable substrate lecithin $(1 \mathrm{mg} / \mathrm{ml})$ or deoxyribose $(0.5 \mathrm{mmol} / \mathrm{L})$. The peroxidation was induced by a typically used agent $\mathrm{FeCl}_{2}(0.1 \mathrm{mmol} / \mathrm{L})$. A sample named Control containing the biologically relevant molecule and $\mathrm{Fe}^{2+}$, was prepared where ART had been omitted. The effect of the compound alone at the maximal tested concentration under the used experimental conditions was also determined. All samples were incubated at $37^{\circ} \mathrm{C}$ for $30 \mathrm{~min}$. Then 0.5 $\mathrm{ml}$ of $2.8 \%$ trichloroacetic acid and $0.5 \mathrm{ml}$ of thiobarbituric acid were added. The mixtures were heated in a boiling water bath at $100^{\circ} \mathrm{C}$ for $20 \mathrm{~min}$. The test tubes were cooled at room temperature and then centrifuged at $3000 \mathrm{rpm}$ for $20 \mathrm{~min}$. The absorbance at $532 \mathrm{~nm}$ was measured. The observed oxidative damage named "molecular damage" was presented as a percentage of the control sample treated only with $\mathrm{Fe}^{2+}$. 


\section{Statistical analysis}

The computer software CalcuSyn (Biosoft, UK) was used to define different parameters: median effect $(\mathrm{Fa})$, combination index (CI), dose reduction index (DRI) and bioequivalent concentrations, and to assess quantitatively the combination drug effect. The experimental data was reported as mean $\pm \mathrm{SD}$ of at least three different experiments $(n=3)$. A student $t$-test was used to determine the difference between the two groups. All the graphs were compiled and statistical analyses were performed using GraphPad Prism.8, MS Excel and Origin Plot.

\section{RESULTS}

\section{Tumor-inhibiting effect}

We first examined the effects of ART and EPI alone on the proliferation of HL-60 and HL-60/Dox cells (Figs 1A, 1B). The MTT assay showed that ART has antitumor activity on HL-60 leukemia cells ( $68 \%$ and $88 \%$ T/C is reached at 400 and $800 \mu \mathrm{mol} / \mathrm{L}$, respectively). Almost the same tumor inhibition was achieved $(61 \%$ - at $400 \mu \mathrm{mol} / \mathrm{L})$ on the resistant HL-60/Dox cells. At lower concentrations (100 and $200 \mu \mathrm{mol} / \mathrm{L}$ ) ART did not show activity over the desired criteria of $50 \%$ and many of the sensitive and resistant cells remained vital. These results show that ART does not have cross-linked resistance with the anthracyclines.

EPI applied separately eliminated approximately all vital HL-60 cells at concentrations of 2.5 and $5 \mu \mathrm{mol} / \mathrm{L}$ but not at $1.25 \mu \mathrm{mol} / \mathrm{L}$. After the combined treatment, markedly stronger anti-proliferation activity was achieved when 200 $\mu \mathrm{mol} / \mathrm{L}$ ART was added to $1.25 \mu \mathrm{mol} / \mathrm{L}$ EPI: the inhibiting effect of the combination was evaluated as $98 \%$, and that is two times more than that of EPI alone. In the other cases it is impossible to analyze comparatively the effectiveness of the combination treatment because EPI alone eliminates all leukemia cells. In contrast, EPI inhibits only less than $10 \%$ in all tested concentrations when applied separately on the resistant HL/60-Dox cells. But co-treatment with ART diminished vitality of the tumor cells in a dose-dependent manner. The tested combination scheme [5 EPI + 400 ART, $\mu \mathrm{mol} / \mathrm{L}]$ reached a maximal inhibiting effect of $92 \%$. This effect is higher than the one achieved by ART alone, and the same as the dose-response of the sensitive leukemia cells to EPI.

\section{Quantitative assay by $\mathrm{Cl}$}

We assessed the effectiveness of varying and fixed-ratio concentrations of [epirubicin+artemisinin]. Synergy on the sensitive HL-60 cells was obtained in varying concentrations only when ART was in the lowest tested concentration of $200 \mu \mathrm{mol} / \mathrm{L}(\mathrm{CI}<0.9)$ (Table $1 \mathrm{~A})$. In the combination $[1.25 \mathrm{EPI}+400 \mathrm{ART}, \mu \mathrm{mol} / \mathrm{L}]$ the observed effect was additive $(0.9<\mathrm{CI}<1.10)$. These effects were confirmed by the results from the estimated fixed-ratio concentration of EPI:ART equal to $1: 160$. The highest tested concentrations of the two drugs, applied simultaneously on HL-60, had CI values higher than one, denoting antagonism. But, as it is shown in Fig. 1A, this is due to the absence of vital cells after exposure with EPI. Only the scheme [1.25 EPI + 200 ART, $\mu \mathrm{mol} / \mathrm{L}]$ had $\mathrm{CI}=0.47$, denoting significant synergism.

The assay of the dose-response on the resistant HL-60/ Dox for varying concentrations of ART and EPI showed higher effectiveness in all of the tested dosage regimens (Table 1B). These CI values denote synergism and potentiation of the tumor inhibition after combination treatment. The same results were obtained for the fixed-ratio concentrations of EPI:ART equal to 1:80 (all values of $\mathrm{CI}<0.9$ ).

\section{Dose modulation effect and DRI}

The dose modulation effect of ART and EPI was evaluated by means of DRI for the fixed ratio concentration on the basis of computer-simulated dose-effect data (Table 2). It was observed that in all cases the concentration of EPI may be diminished according to the indicated concentrations of ART (DRI $>1)$ and the effect $(\mathrm{Fa})$ is conserved at all levels ( $25 \%$ to $90 \%$ inhibition). Favourable reduction of
A
B

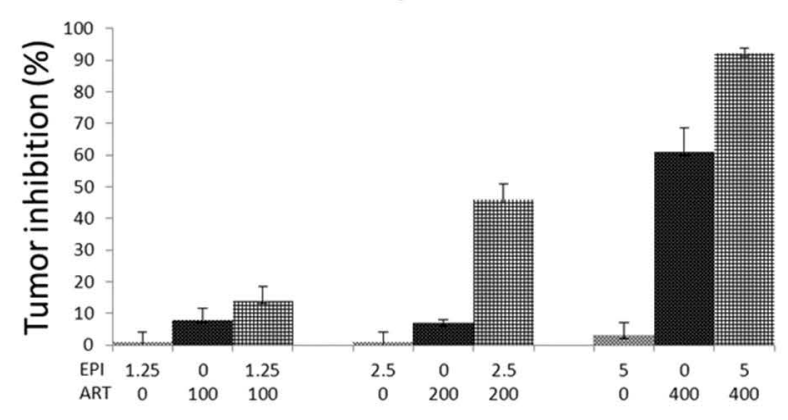

Figure 1. Cytotoxicity of [artemisinin+epirubicin] in leukemia cell lines. A. Dose-response of HL-60 to epirubicin, artemisinin and [artemisinin+epirubicin]. B. Dose-response of HL-60/Dox to epirubicin, artemisinin and [artemisinin+epirubicin]. EPI: epirubicin; ART: artemisinin. 
Table 1. CI values of epirubicin in combination with artemisinin on leukemia cells

\begin{tabular}{llll}
\multicolumn{4}{c}{ 1A } \\
\hline \multicolumn{3}{c}{ HL-60 } \\
\hline $\begin{array}{l}\text { EPI } \\
\mu \mathrm{mol} / \mathrm{L})\end{array}$ & $\begin{array}{l}\text { ART } \\
(\mu \mathrm{mol} / \mathrm{L})\end{array}$ & Fa & CI \pm SD \\
\hline 1.25 & 400 & 0.97 & $0.91 \pm 0.201$ \\
1.25 & 800 & 0.96 & $1.58 \pm 0.790$ \\
2.5 & 200 & 0.98 & $0.87 \pm 0.614$ \\
2.5 & 800 & 0.98 & $1.61 \pm 0.467$ \\
5.0 & 200 & 0.99 & $1.19 \pm 0.326$ \\
5.0 & 400 & 0.99 & $1.39 \pm 0.842$ \\
\hline
\end{tabular}

Fixed ratio concentrations (EPI:ART=1:160)

\begin{tabular}{lll}
\hline Total dose $^{*}$ & Fa & CI \pm SD \\
\hline 201.25 & 0.98 & $0.47 \pm 0.141$ \\
402.5 & 0.98 & $1.05 \pm 0.305$ \\
805 & 0.98 & $2.10 \pm 0.610$ \\
\hline
\end{tabular}

\begin{tabular}{llll}
\hline \multicolumn{4}{c}{ 1B } \\
\hline $\begin{array}{l}\text { EPI } \\
(\mu \mathrm{mol} / \mathrm{L})\end{array}$ & $\begin{array}{l}\text { ART } \\
(\mu \mathrm{mol} / \mathrm{L})\end{array}$ & Fa & CI \pm SD \\
\hline 1.25 & 200 & 0.48 & $0.50 \pm 0.239$ \\
1.25 & 400 & 0.97 & $0.18 \pm 0.141$ \\
2.5 & 100 & 0.16 & $0.57 \pm 0.417$ \\
2.5 & 400 & 0.91 & $0.31 \pm 0.710$ \\
5.0 & 100 & 0.19 & $0.54 \pm 0.632$ \\
5.0 & 200 & 0.47 & $0.52 \pm 0.155$ \\
\hline \multicolumn{5}{c}{ Fixed ratio concentrations } \\
\hline Total dose & \multicolumn{5}{c}{ Fa } & CI \pm SD \\
\hline 101.25 & \multicolumn{5}{c}{0.14} & $0.59 \pm 0.945$ \\
202.5 & \multicolumn{5}{c}{0.46} & $0.52 \pm 0.557$ \\
405 & & 0.92 & $0.29 \pm 0.835$ \\
\hline
\end{tabular}

${ }^{\star}$ Total dose of [epirubicin+artemisininin] in fixed ratio concentrations.

EPI: epirubicin; ART: artemisinin; Fa: median effect; CI: combination index; $\mathrm{CI}<0.9$ denotes synergism, CI=0.9-1.10 - additive effect, and $\mathrm{CI}>1$ - antagonism.

Table 2. DRI values of ART and EPI on HL-60 cells at a fixed ratio $(160: 1)$

\begin{tabular}{lllll}
\hline Fa & $\begin{array}{l}\text { ART } \\
(\mu \mathrm{mol} / \mathbf{L})\end{array}$ & $\begin{array}{l}\text { EPI } \\
(\mu \mathrm{mol} / \mathbf{L})\end{array}$ & DRI $_{\text {ART }}$ & DRI $_{\text {EPI }}$ \\
\hline 0.25 & 222.9 & 0.708 & 2.93 & 5.8 \\
0.35 & 252.4 & 0.83 & 2.08 & 4.3 \\
0.50 & 296.3 & 1.03 & 2.60 & 5.7 \\
0.60 & 329.1 & 1.19 & 1.36 & 3.07 \\
0.70 & 369.0 & 1.39 & 8.24 & 1.93 \\
0.75 & 393.9 & 1.52 & 0.002 & 5.51 \\
0.90 & 523.6 & 2.21 & 0.203 & 5.36 \\
\hline
\end{tabular}

DRI: Dose reduction index; DRI $>1$ denotes favourable reduction of the dose; EPI: epirubicin; ART: artemisinin.

the dose of ART is also possible in the combinations that reach up to $70 \%$ inhibition. This means that we do not need to use concentrations of ART more than $400 \mu \mathrm{mol} / \mathrm{L}$ when EPI is applied in smaller concentrations $(1.52 \mu \mathrm{mol} / \mathrm{L})$. The results from the computer-simulated "dose-effect" correspond adequately to the synergistic effect of ART and EPI when applied in smaller concentrations - 200 and 1.25 $\mu \mathrm{mol} / \mathrm{L}$, respectively.

\section{Comparative analysis on the basis of $\mathrm{IC}_{50}$}

EPI and ART reach 50\% inhibition on the HL-60 cells in near concentrations in both the separate and combined treatment (Comfix) (Table 3). However, while EPI 5
Table 3. Bioequivalent $\mathrm{IC}_{50}$ concentrations of artemisinin, epirubicin and the fixed-ratio combinations on HL-60 and HL-60/Dox

\begin{tabular}{lll}
\hline $\mathrm{IC}_{\mathbf{5 0}}(\boldsymbol{\mu m o l} / \mathrm{L})$ & HL-60 $\pm \mathrm{SD}$ & HL-60/Dox \pm SD \\
\hline Artemisinin & $307.7 \pm 33$ & $360.2 \pm 40$ \\
Epirubicin & $1.25 \pm 0.5$ & $>>5$ \\
Comfix 1:160* & {$[1.03 \pm 0.5+296.3 \pm 10.5]$} & --- \\
Comfix 1:80* & --- & {$[2.4 \pm 0.25+190.1 \pm 40]$} \\
\hline
\end{tabular}

*[epirubicin+artemisinin] according to COMPUSYN analysis.

$\mu \mathrm{mol} / \mathrm{L}$ does not influence the MDR HL-60/Dox cells alone, it is effective at $2.4 \mu \mathrm{mol} / \mathrm{L}$ when used in combination with $190 \mu \mathrm{mol} / \mathrm{L}$ ART. Moreover, this dose for ART is 1.8 times smaller than the one when ART is applied alone. Thus, the evaluated ratio of EPI:ART equal to 1:80 proves to be a better choice for applied treatment of the HL- 60 cells. Interestingly, the combined treatment with ART and EPI on HL-60/Dox resistant cells causes 50\% inhibition in smaller concentrations than these on HL-60 cells.

\section{Modulation effect of artemisinin on iron- induced oxidative molecular damage}

\section{Lipid peroxidation assay}

Some extent of oxidative molecular damage was evident in all samples, including the one only with the oxidizable substrate lecithin $(1 \mathrm{mg} / \mathrm{ml})$ where only autoxidation processes triggered by the experimental conditions were expected 
(Fig. 2). The measured absorbance of this sample was 0.092 which is corresponding to $22.15 \%$ molecular damage when compared to the control. The extinctions of the samples containing ART and lecithin were a little bit higher compared to the one containing only lecithin but no statistically significant differences were observed. In the presence of iron and ART the absorbance values of the samples were more than three times higher compared to the sample containing only ART. The extent of molecular damage observed in the three tested concentrations of ART $(96.05 \%$ to $102.74 \%$ ) was identical to the control.

\section{2-deoxyribose degradation assay}

The extent of the observed molecular damage in the different samples depended on a number of factors - sample constituents and the used concentration of ART (Fig. 3). In the sample containing only 2-deoxyribose, minimal increase of the absorbance value at $532 \mathrm{~nm}$ was observed. This indicates negligibly low extent of 2-deoxyribose degradation triggered by the applied experimental conditions. In the sample containing the used substrate and ART (0.95 $\mathrm{mmol} / \mathrm{l})$ the observed absorbance value was more than 20 times higher compared to the samples containing

\section{Artemisinin - lecithin}

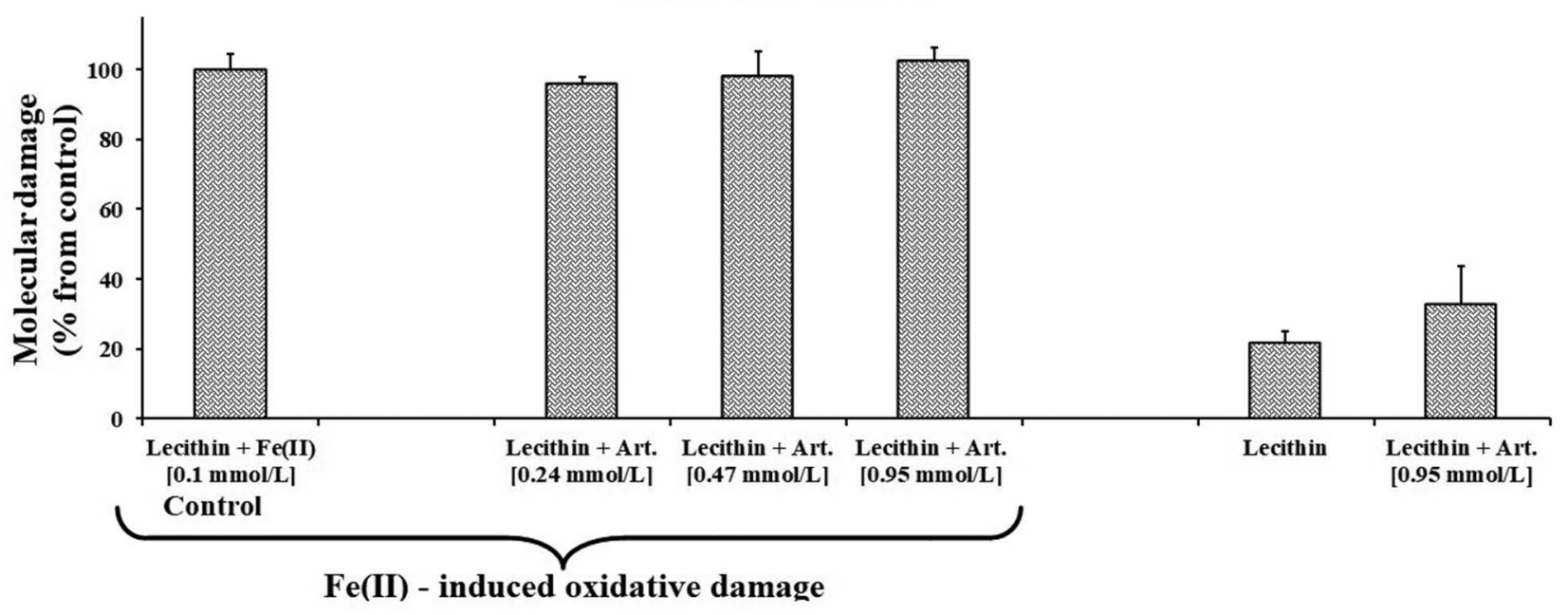

Figure 2. Degree of lecithin oxidative molecular damage. Lecithin $(1 \mathrm{mg} / \mathrm{ml})$ was incubated with $0.1 \mathrm{mmol} / \mathrm{L} \mathrm{Fe}(\mathrm{II})$ in the absence or presence of artemisinin. Data are reported as means \pm SD of percentage of control for 3 separate measurements.

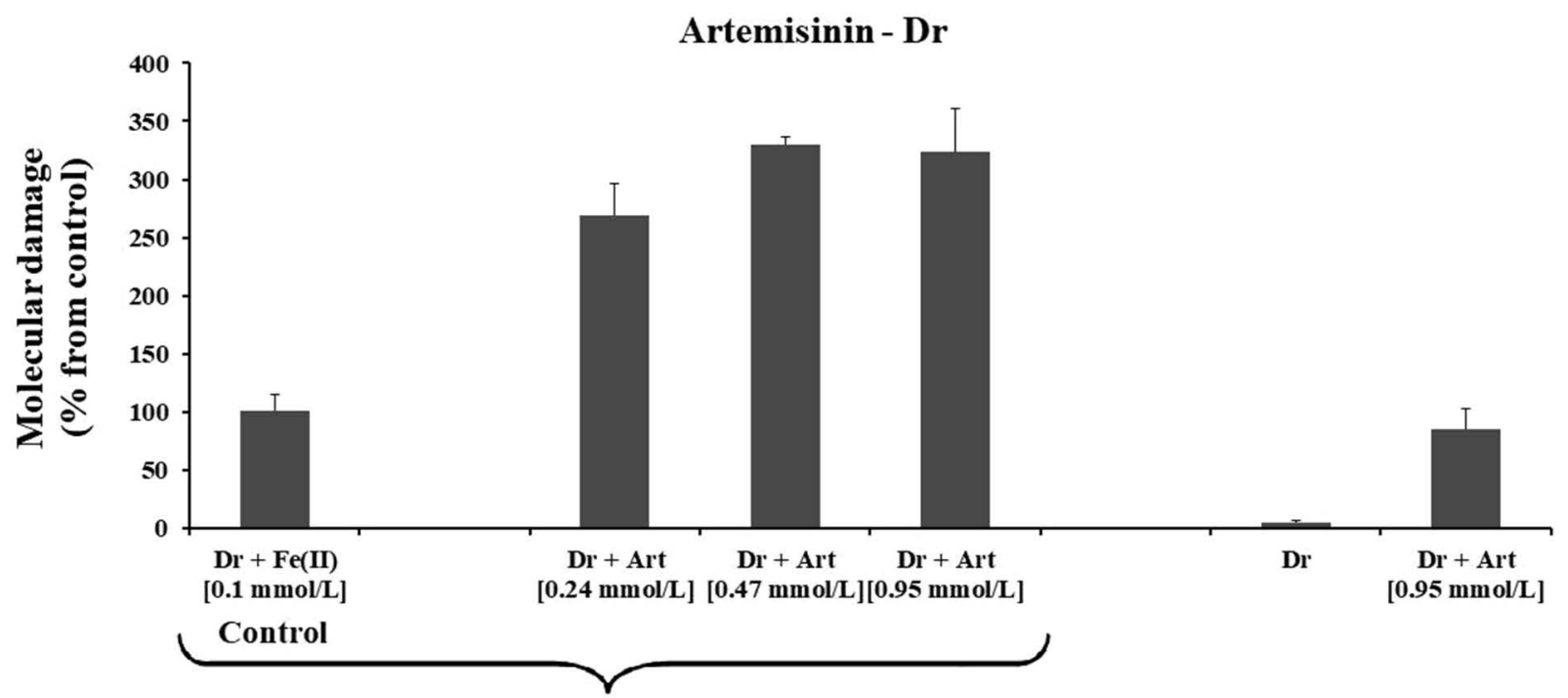

Fe (II) - induced oxidative damage

Figure 3. Degree of 2-deoxyribose oxidative molecular damage. Deoxyribose $(0.5 \mathrm{mmol} / \mathrm{L})$ was incubated with $0.1 \mathrm{mmol} / \mathrm{L} \mathrm{Fe}(\mathrm{II})$ in the absence or presence of artemisinin. Data are reported as means \pm SD of percentage of control for 3 separate measurements. Dr: 2-deoxyribose; Art: artemisinin. 
only the 2-deoxyribose. The estimated molecular damage was $84.65 \%$, close to the observed in the control samples. In the presence of both iron and ART the absorbance values of the samples were two to three times higher compared to the control. These results suggest an increase of TBARS products, deoxyribose degradation and molecular damage.

\section{DISCUSSION}

Combination chemotherapy is the main approach in treating resistant and advanced malignant tumors. In this study we comparatively evaluated the tumor-inhibiting effect of artemisinin, epirubicin and the combination of the two drugs at varying and fixed-ratio concentrations on sensitive and MDR-resistant HL-60 cell lines. Artemisinin potentiates epirubicin-induced cytotoxicity on HL-60/Dox cells as revealed by the reached tumor inhibition and the CI values (Fig. 1B; Table 2). Comparison between the dose-response on the sensitive HL-60 and the resistant leukemia cells shows increase of the tumor inhibition on HL60/Dox cells in dependence of the applied concentrations of ART. Our results confirm that ART has a modulating effect against EPI on resistant tumor cells.

Some investigators obtained antagonism between artemisinin and doxorubicin on HT29 colon cancer cells and MCF-7 breast cancer cells due to the P-gp expression when artemisinin was applied as pre-treatment. ${ }^{16}$ But it is known that the effect of the combination treatment depends not only on the kind of the components but also on the type of tumor cells, tested concentrations and the mechanism of its antitumor action, including presence of $\mathrm{Fe}^{2+}$ needed for bioactivation of the bioreductive drugs. However, detailed investigations of different tumor cell models are required for a definitive conclusion. In this aspect, the application of the quantitative assay based on the mathematical algorithm of Chou Talalay ${ }^{19,20}$ may improve the experimental design of the combination therapy. In our study we define that the combination of EPI with ART is highly effective and makes it possible to apply lower EPI concentrations than $\mathrm{IC}_{50}$. In addition, we obtained that the ratio between EPI and ART of $1: 80$ is synergistic $(\mathrm{CI}<0.59)$ and effective on resistant HL-60/Dox cells, reaching 92\% anti-proliferative effect. This may be important as a prognostic factor for the treatment of resistant human tumors.

The study of artemisinin in the lecithin-containing system demonstrates that the drug does not change the extent of iron-induced oxidative damage of lecithin at in vitro conditions in the presence and absence of iron. This suggests that in this case it is not likely to observe generation of end lipid peroxidation products which are typical for many cytostatic drugs. ${ }^{22}$ The obtained results are in accordance with other authors' reports who observe that when administered alone ART has no effect on plasma TBARs and the membrane fluidity in in vitro culture and malaria patients. ${ }^{23}$

The effect of ART on the 2-deoxyribose degradation was similar to the one induced by iron. Artemisinin denoted its capability to induce deoxyribose oxidative degradation and exert synergistic effect with iron. The modulation effect of ART (at cell level and oxidative damages) is consistent with the data reported by $\mathrm{Wu}$ et $\mathrm{al}^{24}$ for dihydroartemisinin which sensitized cells to apoptosis induced by doxorubicin. Our results from the lipid peroxidation assay and the deoxyribose degradation assay add to the gathered knowledge for the radical-induced mechanisms of cytotoxicity of artemisinin.

\section{CONCLUSIONS}

Artemisinin synergistically increases the epirubicin-induced inhibition of HL-60/Dox resistant cells when applied in varying or fixed-ratio (1:80) concentrations. The synergism is partially associated with the sensitization of the tumor cells to the cytostatic. Artemisinin shows a favourable dose modulation effect towards epirubicin on sensitive HL-60 cells. In regards to its mechanism of action, our results show that artemisinin induces deoxyribose molecular damage to an extent similar to the iron-induced oxidation, and this effect is even higher when artemisinin is applied in the presence of $\mathrm{Fe}^{2+}$. Thus, the combination of [artemisinin+epirubicin] on multi-resistant tumor cells may be a promising strategy for cancer treatment. Nevertheless, further research is needed to define the spectrum of artemisinin's combined antitumor activity.

\section{REFERENCES}

1. Epirubicin, monongraph. British Columbia: BC Cancer Agency; Vancouver 2017.

2. Tu Y. Artemisinin - a gift from traditional Chinese medicine to the world (Nobel Lecture). Angew Chem Int Edit 2016; 55(35):10210-26.

3. Ericsson T, Blank A, von Hagens C, et al. Population pharmacokinetics of artesunate and dihydroartemisinin during long-term oral administration of artesunate to patients with metastatic breast cancer. Eur J Clin Pharmacol 2014; 70:1453-63.

4. Wong $\mathrm{YK}, \mathrm{Xu} \mathrm{Ch}$, Kalesh $\mathrm{KA}$, et al. Artemisinin as an anticancer drug: Recent advances in target profiling and mechanisms of action. Medicinal Research Reviews 2017; 37(6):1492-517.

5. Zhou HJ, Zhang JL, Li A, et al. Dihydroartemisinin improves the efficiency of chemotherapeutics in lung carcinomas in vivo and inhibits murine Lewis lung carcinoma cell line growth in vitro. Cancer Chemother Pharmacol 2010; 66(1):21-9.

6. Hwang YP, Yun HJ, Kim HG, et al. Suppression of PMA-induced tumor cell invasion by dihydroartemisinin via inhibition of PKCalpha/ Raf/MAPKs and NF-kappaB/AP-1-dependent mechanisms. Biochem Pharmacol 2010; 79(12):1714-26.

7. Yu H, Guo P, Xie X, et al. Ferroptosis, a new form of cell death, and its relationships with tumourous diseases. J Cell Mol Med 2017; 21(4):648-57.

8. Dixon SJ, Lemberg KM, Lamprecht MR, et al. Ferroptosis: an iron-dependent form of nonapoptotic cell death. Cell 2012; 149(5):1060-72. 
9. Chen T, Li M, Zhang R, et al. Dihydroartemisinin induces apoptosis and sensitizes human ovarian cancer cells to carboplatin therapy. J Cell Mol Med 2009; 13(7):1358-70.

10. Li Z, Li Q, Wu J, et al. Artemisinin and its derivatives as a repurposing anticancer agent: what else do we need to do? Molecules 2016, 21:1331.

11. Mercer AE, Maggs JL, Sun XM, et al. Evidence for the involvement of carbon-centered radicals in the induction of apoptotic cell death by artemisinin compounds. J Biol Chem 2007; 282: 9372-82.

12. Nakase I, Gallis B, Takatani NT, et al. Transferrin receptor-dependent cytotoxicity of artemisinin-transferrin conjugates on prostate cancer cells and induction of apoptosis. Cancer Lett 2009; 274:290-8.

13. Yang ND, Tan SH, Ng S, et al. Artesunate induces cell death in human cancer cells via enhancing lysosomal function and lysosomal degradation of ferritin. J Biol Chem 2014; 289(48):33425-41.

14. Reungpatthanaphong P, Mankhetkorn S. Modulation of multidrug resistance by artemisinin, artesunate and dihydroartemisinin in K562/Adr and GLC4/Adr resistant cell lines. Biol Pharm Bull 2002; 25:1555-61.

15. Gravett AM, Liu WM, Krishna S, et al. In vitro study of the anticancer effects of artemisone alone or in combination with other chemotherapeutic agents. Cancer Chemother Pharmacol 2011; 67(3):569-77.

16. Riganti C, Doublier S, Viarisio D, et al. Artemisinin induces doxorubicin resistance in human colon cancer cells via calcium-depen- dent activation of HIF- $1 \alpha$ and P-glycoprotein overexpression. Br J Pharmacol 2009; 156(7):1054-66.

17. Hou J, Wang D, Zhang R, et al. Experimental therapy of hepatoma with artemisinin and its derivatives: in vitro and in vivo activity, chemosensitization, and mechanisms of action. Clin Cancer Res 2008; 14:5519-30.

18. Krasteva I, Yotova M, Konstantinov S, et al. Cytotoxicity of gypsogenic acid isolated from Gypsophila trichotoma. Pharmacogn Mag 2014; 10(Suppl 2):S430-3.

19. Chou TC, Talalay P. Quantitive analysis of dose-effect relationships: the combined effects of multiple drugs or enzyme inhibitors. Adv Enzyme Regul 1984; 22:27-55.

20. Ting-Chao Chou. Drug combination studies and their synergy quantification using the Chou-Talalay method. Cancer Res 2010; (70)2:440-6.

21. Asakawa T, Matsushita S. Coloring conditions of thiobarbituric acid test for detecting lipid hydroperoxides. Lipids 1980; 15:137-40.

22. Barrera G. Oxidative stress and lipid peroxidation products in cancer progression and therapy. ISRN Oncol 2012; 2012:137289.

23. Sibmooh N, Pipitaporn B, Wilairatana P, et al. Effect of artemisinin on lipid peroxidation and fluidity of the erythrocyte membrane in malaria. Biol Pharm Bull 2000; 11(23):1275-80.

24. Wu GS, Lu JJ, Guo JJ, et al. Synergistic anti-cancer activity of the combination of dihydroartemisinin and doxorubicin in breast cancer cells. Pharmacol Rep 2013; 65(2):453-9. 


\title{
Противоопухолевая активность комбинации артемизинина и эпирубицина в лейкозных клетках человека
}

\author{
Маргарита Я. Желязкова ${ }^{1}$, Надя Г. Христова-Авакумова ${ }^{2}$, Георги Цв. Момеков ${ }^{1}$ \\ ${ }^{1}$ Кафедра фармакологии, фармакотерапии и токсикологии, Фармацевтический факультет, Медицинский университет - София, София, \\ Болгария \\ ${ }^{2}$ Кафедра медицинской физики и биофизики, Медицински университет - София, София, Болгария
}

Адрес для корреспонденции: Маргарита Я. Желязкова, Кафедра фармакологии, фармакотерапии и токсикологии, Фармацевтический факультет, Медицинский университет - София, София, Болгария; E-mail: maggie.zhe1711@gmail.com; Тел.: 029236509

Дата получения: 29 июня 2020 Дата приемки: 30 июля $2020 \diamond$ Дата публикации: 31 августа 2021

Образец цитирования: Zhelyazkova MY, Hristova-Avakumova NG, Momekov GTsv. Antitumor activity of the combination of artemisinin and epirubicin in human leukemia cells. Folia Med (Plovdiv) 2021;63(4):488-95. doi: 10.3897/folmed.63.e55938.

\section{Резюме \\ Введение: Мы оценили подавляющий опухоль эффект артемизинина, вводимого отдельно и в комбинации с эпирубици- ном, на лейкемические клеточные линии HL-60 и HL-60/Dox, его эффект модуляции дозы и его способность влиять на вы- званное железом окислительное повреждение биологически релевантных молекул.}

Материалы и методы: Для демонстрации ингибирования пролиферации опухолевых клеток и оценки синергетического и модулирующего действия артемизинина и эпирубицина в различных концентрациях использовали МТT-тест и метод СhоuTalalay Кроме того, мы использовали спектрофотометрический анализ для определения способности артемизинина влиять на индуцированную железом молекулярную деградацию лецитина и дезоксирибозы.

Результаты: Артемизинин показал ингибирующее действие на опухоль как на антрациклин-чувствительные, так и на антрациклино-устойчивые клеточные линии промиелоцитов, достигая $88 \%$ и $61 \%$ (Т/C), соответственно, при дозозависимом введении в более высоких концентрациях. Комбинация артемизинина и эпирубицина выявила синергетический эффект при всех концентрациях, изученных на доксорубицин-резистентных клетках (DI $<0.7)$. Артемизинин сенсибилизирует эпирубицин-резистентные клетки, что подтверждается значениями доверительного интервала (ДИ), и имеет дозо-модулирующий эффект, как видно из DRI. Артемизинин вызывает окислительную деградацию дезоксирибозы при введении отдельно и обладает синергическим эффектом деградации дезоксирибозы при введении с железом. Однако артемизинин не влиял на исследуемую модельную систему, содержащую лецитин, и не обладал потенциалом индуцировать перекисное окисление липидов.

Заключение: Это исследование представляет новую возможность для повышения эффективности схем лечения на основе эпирубицина с добавлением артемизинина для резистентных опухолей.

\section{Ключевые слова}

комбинированная химиотерапия, дезоксирибоза, HL-60 / Dox, лецитин, синергизм 